\title{
Financial and Technical Analyses of Solar Boats as A Means of Sustainable Transportation
}

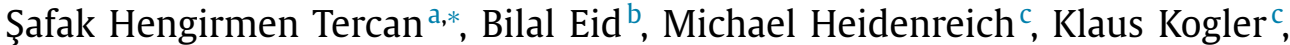 \\ Ömer Akyürek ${ }^{\mathrm{d}}$
}

a Department of Civil Engineering, Hasan Kalyoncu University, Gaziantep, Turkey

${ }^{\mathrm{b}}$ Department of Electrical and Electronics Engineering, Hasan Kalyoncu University, Gaziantep, Turkey

' CES Clean Energy Solutions GesmbH Schönbrunner Str. 297, 1120 Wien, Österreich

${ }^{\mathrm{d}}$ Demir Energy, Istanbul, Turkey

\section{A R T I C L E I N F O}

\section{Article history:}

Received 15 July 2020

Revised 19 November 2020

Accepted 21 November 2020

Available online 24 November 2020

Editor: Prof. Adisa Azapagic

\section{Keywords:}

Sustainable Transportation

Climate Change

Solar Boat

Sustainable Production and Consumption

Off-grid Photovoltaic Systems

Financial Analysis

\begin{abstract}
A B S T R A C T
Because of the effects of climate change, a sustainable transportation system based on renewable energy resources needs to be developed to improve the quality of life. In this study, three sustainable transportation designs and an on-grid power plant design using photovoltaic (PV) panels were analyzed for their feasibility as an alternative to diesel-powered tourist boats. Various financial and technical aspects were considered, such as the local irradiation, energy yield, and system energy loss. As a case study, a solaraided boat was considered, where an off-grid rooftop PV system with $9.8 \mathrm{kWh}$ batteries was installed to meet the energy requirements for internal services and reduce diesel usage. The solar-aided boat was demonstrated to be an economical solution, where the PV system reduced the diesel consumption of the boat by $15 \%$ and produced an annual energy output of $5540 \mathrm{kWh}$. For fully electric solar boats, simulation results showed that a $60 \mathrm{kWh}$ battery system covers the initial investment within 9 years, while a solar boat with $120 \mathrm{kWh}$ a battery system covers it in 13 years. A $300 \mathrm{~kW}$ on-grid PV plant was analyzed for its ability to meet the energy demands of an entire tourist boat fleet, and the plant was estimated to reduce $\mathrm{CO}_{2}$ emissions by 330 tons each year. These findings show that various off-grid rooftop PV systems can be adapted for sustainable transportation while reducing the operating costs of the boat. This study also promotes the transition of boats to cleaner and more sustainable energy sources.
\end{abstract}

(C) 2020 Institution of Chemical Engineers. Published by Elsevier B.V. All rights reserved.

\section{Introduction}

Climate change is a global problem in the $21^{\text {st }}$ century, and urban sustainability has been identified as a critical challenge for humans (Nations, 2015). Various regions are expected to encounter many difficulties, such as droughts, high temperatures, heavy rain, and windstorms. Energy experts have been searching for methods to adapt to and mitigate climate change in specific regions such as islands, coasts, river basins, and wetlands. These regions are attractive to tourists and welcome many activities such as boat tours. Australia has many examples of such regions with a 35,000$\mathrm{km}$-long coastline. In Australia, marine attractions make up 70,000 tons $\mathrm{CO}_{2}$ eq. or $1 \%$ of the annual greenhouse gas emissions from the transportation sector. Case studies of Australian boat tour operators have shown that each tourist has a carbon footprint of 61 $\mathrm{kg} \mathrm{CO} 2$ eq. if they join a boat tour with a diesel motor and $27 \mathrm{~kg}$

\footnotetext{
* Corresponding author. GSM: +90 5323912547.

E-mail address: safakhengirmen@hotmail.com (Ş.H. Tercan).
}

$\mathrm{CO}_{2}$ eq. if the boat has a petrol motor (Byrnes and Warnken, 2006). These carbon footprints are equivalent to a single individual driving 300 or $140 \mathrm{~km}$, respectively, in a standard passenger vehicle.

Many islands are also facing the negative impacts of tourism. A number of island destinations have become synonymous with massive tourism, particularly in the Mediterranean and Caribbean Seas. While their geographical, cultural, ecological, and economic features attract visitors, the fragility and limitations of such features mean that both the island environment and communities are weak against the pressures of tourism (Kokkranikal et al., 2003). Renewable energy could be a sophisticated solution to such difficulties, but this requires more technological and institutional advances for implementation. Some projects have focused on implementing micro-grid projects consisting of photovoltaic (PV) systems (Eid et al., 2014). In Thailand (Veilleux et al., 2020), Koh Jik Island has been used to model a series of micro-grid projects to obtain techno-economic insights into rural electrification. The minimum cost of electricity was obtained with lithium-ion batteries at $0.220 \mathrm{EUR} / \mathrm{kWh}$; when compared to the cost of $0.307 \mathrm{EUR} / \mathrm{kWh}$ 
for lead-acid batteries, this translates into a payback period of as short as 6.3 years with an internal rate of return of $15.28 \%$. Another micro-grid project was implemented in the Maldives, which has many villages on remote islands that rely on diesel for power generation. This project implemented a hybrid design consisting of wind and solar power systems. The end users participating in the project adjusted their activities to reduce the load when requested. The results demonstrated a key concept for energy transition: a $100 \%$ transition to renewable energy is not a reasonable substitute for fossil fuels. Demand habits developed when fossil fuels were abundant and low in cost (Fulhu et al., 2019).

Globally, the renewable energy sector has been increasing in size, and increasingly ambitious targets are being set. Most countries signed the Paris Agreement in 2015, and they have set targets for decreasing their own greenhouse gas emissions and achieving $100 \%$ of their energy coming from renewable sources in the next few decades. In a study on the Danish energy system, the results showed that the current electricity market structure cannot financially sustain the amount of wind power necessary to transition to a scenario of $100 \%$ renewable energy use by 2050 . Remodeling this structure could help Denmark achieve this goal (Djorup et al., 2018). Turkey is located in the Mediterranean basin and has a high renewable energy potential but also many regulations for utilization. Turkey has realized a renewable energy potential equal to $13 \%$ of the total renewable energy potential of the European Union nations. In recent years, advances in technologies such as solar and wind power have made them more effective for energy production (Bulut and Muratoglu, 2018).

Solar boats refer to electric boats powered by solar energy. The technical aspects of solar boats include the assembly of PV panels, batteries, and electric motor in the hull. In this study, the technical and financial aspects of applying several PV systems to an existing boat were evaluated to assess the feasibility of transitioning to a sustainable transportation mode. A case study was performed to investigate the benefits of installing PV panels on the rooftop of a tourist boat to supply the energy for internal services. The PV panels generated electricity as the boat sailed or waited in the marina without any need for infrastructure such as charging points. The generated electricity was consumed by the lighting, refrigeration, hot drinks, pumps, navigation, and sound systems of the boat. This paper shows that various off-grid rooftop PV systems can be easily adapted for sustainable transportation to reduce the operating costs of boat owners. The results of the analysis demonstrate that the negative environmental impacts of boats can be reduced, which can help in efforts to mitigate climate change.

\section{Literature Review}

In recent decades, the importance of the relationship between tourism, transportation, and the environment has been increasing (Blancas et al., 2018, Mihalic, 2016). Tourism-based transportation threatens nature and natural resources while increasing pollution (Wang et al., 2019, Azam et al., 2018, Høyer, 2000). The Sustainable Development Goals of the United Nations recommends that countries focus on sustainable tourism activities to ensure their social, economic, and environmental well-being (Nations, 2015). Sustainable transportation modes are an important tool for supporting sustainable tourism.

Solar boats reduce the negative impact of motorboats and contribute to sustainability (Del Pizzo et al., 2010, Bianucci et al., 2015) by helping achieve the goal of reducing $\mathrm{CO}_{2}$ emissions by up to 50\% (Łebkowski, 2017, Karimpour and Karimpour, 2016). Factors such as environmental health, the preservation of clean water resources, rising energy costs, and a limited budget are forcing tourist boat owners and local authorities to find cost-efficient solutions for achieving sustainability. Low-cost and high-quality so- lar boats are an innovative solution with growing relevance, but awareness about the profitability of solar boats is insufficient. The related high costs have prevented wide usage so far, and financial mechanisms are needed to facilitate the use of solar boats.

The "willingness to pay" of tourists can be used to develop a financial model. One study investigated whether tourists are willing to pay for the introduction of electric boats in Lake Trasimeno Regional Park, which is a protected area in Italy. Two alternative boat types were considered: hybrid and fully electric. The tourists' willingness to pay was found to cover more than half of the purchase price of the hybrid electric boat and one-fifth of the purchase price of the fully electric boat. The study also investigated the reduction in $\mathrm{CO}_{2}$ emissions and concluded that the earnings from selling carbon credits would be insufficient to convince ferry operators to buy one of these alternatives (Bigerna et al., 2019).

Since 2000, many studies have focused on sustainable transportation. A review on sustainable transportation between 2000 and 2019 found that the development of new fuels for vehicles is an active research topic, while more research is needed on topics such as resilient and sustainable transportation (Zhao et al., 2020). Accordingly, some researchers have been working on solar power as a new alternative fuel (Faulin et al., 2019) that can be used to meet the needs of services provided on boats. For example, one study in Tanzania focused on fishers who use kerosene lanterns to attract fish to their nets. These fishers were spending 35\%-50\% of their take-home pay on lighting equipment and fuel. The researchers suggested a battery-powered LED lighting system, which has a payback period of 3-4 months, and provided a roadmap for deployment (Mills et al., 2014). Another study compared the specifications and prices of selected low- and medium-power internal combustion motors and batteries for yachts. They found that electric motors are a good alternative to internal combustion motors when a low power level is required, but the conventional internal combustion motor is preferable when a high power level is required (Łapko, 2016).

Electric propulsion systems are widely applied in modern ships, including transportation ships and warships. Researchers have been working on fully electric ships that use electricity not only for its propulsion but also for other vital functions such as navigation and other services (Spyropoulos et al., 2013). Electric boats are gaining interest around the world as an emerging technology, similar to electric cars. However, docks and marinas generally do not have electric charging points. Thus, an innovative and effective solution is to install PV panels as a standalone system on the boat. Several solar boats have already been introduced to the market and are presented below in Table 1. (https://www.bootemagazin.de/ratgeber/berechnungen.html April 2017).

\section{Methods}

\subsection{Boat Specifications and Simulation Model}

In this study, three sustainable transportation designs and an on-grid power plant using PV panels were analyzed for their feasibility as alternatives to diesel-powered tourist boats. For the case study, a solar-aided boat was considered where PV panels were installed with a $9.8 \mathrm{kWh}$ battery system to meet the energy needs for internal services. Then, fully electric solar boats were considered with $60 \mathrm{kWh}$ and $120 \mathrm{kWh}$ battery systems. The on-grid power plant was used to consider the feasibility of converting a tourist boat fleet to fully electric boats. The PV*SOL simulation software was used to evaluate the different designs. PV*SOL can consider many factors such as the size and direction of the system, number and duration of use of electric devices, the general climatic conditions of the region, and the associated solar radiation and local grid distribution (PV*SOL software August 2018). The required 
battery system and inverter power were determined by calculating the system capacity, annual power generation, and performance of the solar boat designs.

For the case study, the most common boat design for tourist boats in the study area was selected. The technical details were collected from onsite observations. The boat length and width were 14 and $4.90 \mathrm{~m}$, respectively. The boat had two floors, and 15 PV panels were installed on the rooftop. The boat weighed 25 tons and had a capacity of 45 passengers. Gel batteries were selected because of their efficiency. The total weight of the batteries was nearly $100 \mathrm{~kg}$, which is negligible with regard to diesel consumption for propulsion. Alternative fuels such as compressed natural gas and hydrogen were not considered because their supply chains are not available in the study area. Fig. 1 shows the required motor power for $1 \mathrm{~h}$ of driving at a constant speed for various boat weights. A boat weight reduction of $1 \%$ is equivalent to a power demand reduction of $0.44 \%$. In the study area, boats travel at speeds of $6-10 \mathrm{~km} / \mathrm{h}(3.2-5.4 \mathrm{kn})$. This results in a power demand of $10-20 \mathrm{~kW}$.

\subsection{Functional Analysis}

The challenge with solar boats is developing a design that is attractive to the local market. An adequate business model needs to be developed to address financial hurdles. A functional analysis was performed to assess the ability of solar boats to meet user needs in comparison with diesel-powered competitors to highlight their sustainability. Within this context, the functional analysis focused on identifying the needs of boat owners and determining how these needs can be fulfilled. The solar boats and dieselpowered boat were then assessed on their abilities to fulfill these needs. Functions were defined and used as criteria for analyzing which boat design best fit the users' needs, which were identified based on interviews with experts who have worked in the market. Boat designs were given a score of 1 (minimum) to 10 (maximum) based on how well they met each function. Table 2 connects functions with criteria. Fig. 2 shows the strengths and weaknesses of each design.

\subsection{Case Study}

Gaziantep-Rumkale-Halfeti, Turkey is a touristic region on the Euphrates River. Most of the old village was submerged in the 1990s by the water behind a constructed dam. Diesel-powered tourist boats frequently operate on this dam lake for tourist activities. A fleet of 40 boats travels $40 \mathrm{~min}$ to the base of a rocky bluff, on top of which sits a ruined fortress. The fortress features a mosque, church, and monastery, all of which are relatively well preserved. Depending on the number of tourists and travel demand, the boats operate up to five times a day. In this area, the annual average solar irradiation time is $2978 \mathrm{~h}$, and the total solar energy potential is $1586 \mathrm{kWh} / \mathrm{m}^{2}$ (Solar Irradiation Turkey 2019). This implies that a PV installation capacity of $100 \mathrm{kWp}$ can produce $166,100 \mathrm{kWh}$ of energy per year.

To simulate the PV system, commercially available PV panels were assumed to cover a horizontal rooftop area of roughly $25 \mathrm{~m}^{2}$. Climatic data for the study area were used to simulate the specific yield of each design. Table 3 presents the monthly yield for the study area simulated in PV*SOL. The rooftop PV system was found to achieve an annual yield of $200 \mathrm{kWh} / \mathrm{m}^{2}$ and peak capacity of $150 \mathrm{Wp} / \mathrm{m}^{2}$ (one panel covers about $1.70 \mathrm{~m}^{2}$ ). When only solar power is used to drive the electric motor, the solar boat is very slow. Thus, a battery system of sufficient size is also required, as demonstrated by the commercially available boats discussed in Section 2. 


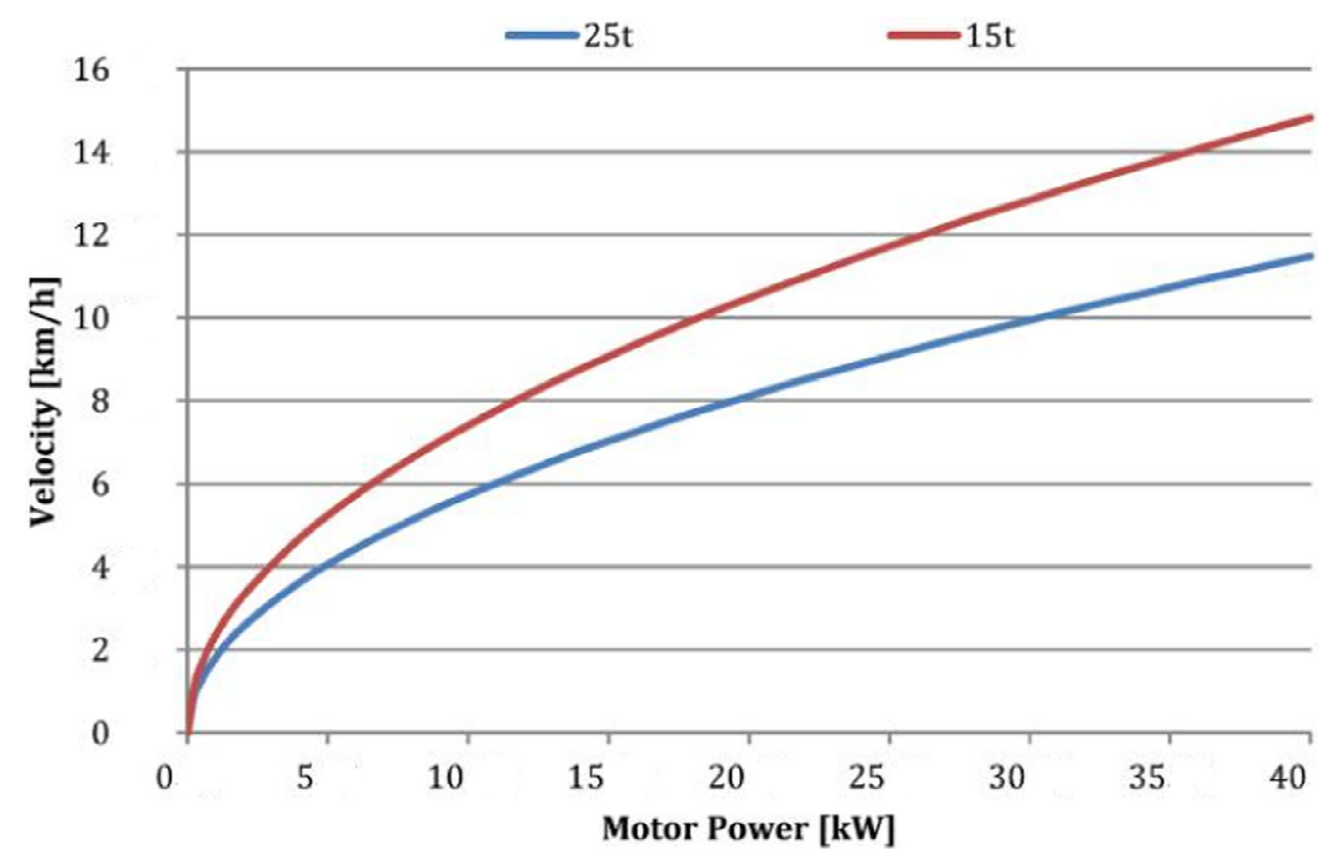

Fig. 1. Relationship between engine power for various speed levels and weights (https://www.boote-magazin.de/ratgeber/berechnungen.html April 2017).

Table 2

Functional analysis table.

\begin{tabular}{ll}
\hline Function & Criteria \\
\hline $\begin{array}{l}\text { Technical and economic functions } \\
\text { Adaptable to any types of boats }\end{array}$ & Size and geometry \\
& Equipment and appliances \\
& Assembling \\
& Integration into existing system \\
Comply with relevant regulations \& standards & Legal obligations/references \\
& Safety issues \\
& Procurement procedures \\
Compatible with other technologies & Appliances \\
& Battery \\
Easy and safe implementations & Installation time \\
& Onsite equipment \\
Performance guarantee & Skill of craftsmen \\
Affordability & Contract about performance \& maintenance \\
& Validation procedure \\
& Investment costs \\
\hline
\end{tabular}

Table 3

Specific yield forecast by $\mathrm{PV} * \mathrm{SOL}$

sofware.

\begin{tabular}{lll}
\hline \multicolumn{3}{c}{ Specific Yield } \\
\hline Month & Wh $/ \mathrm{m}^{2} / \mathrm{d}$ & $\mathrm{kWh} / \mathrm{d}$ \\
JAN & 275 & 6.88 \\
FEB & 352 & 8.8 \\
MAR & 543 & 13.56 \\
APR & 687 & 17.18 \\
MAY & 766 & 19.15 \\
JUN & 874 & 21.86 \\
JUL & 849 & 21.21 \\
AUG & 761 & 19.02 \\
SEP & 659 & 16.47 \\
OCT & 486 & 12.15 \\
NOV & 349 & 8.73 \\
DEC & 272 & 6.79 \\
\hline
\end{tabular}

Solar-powered systems consist of the PV panels, batteries, and the related control system. EU Directive 92/75/EEC (EU Directive 92/75/EEC April 2017) established an energy consumption label- ing scheme that also applies to boats. Energy management involves optimizing the balance of the system according to the load demands. For effective energy management, the supply from the PV panels, battery capacity, and energy consumption need to be calculated correctly. The rooftop area of the boat is clearly too small for PV panels to produce enough electricity to replace the diesel motor with an electric motor. Thus, only the service demands were considered for energy consumption: lighting, refrigeration, hot drinks, pumps, navigation, and the sound system. The intention was to minimize the energy demand to limit the size of the PV panels and necessary battery capacity. Fifteen PV panels with dimensions of $1647 \times 992 \times 40 \mathrm{~mm}$ were installed on the rooftop of the tourist boat. These PV panels had an efficiency of $16.62 \%$ and capacity of $270 \mathrm{~W}$. An inverter with a capacity of $4400 \mathrm{~W}$ and four gel batteries (12 V, $200 \mathrm{Ah}$ ) were integrated in the boat. Fig. 3 shows a line diagram of the installed system.

Fig. 4 shows the boat equipped with PV panels. The PV system provided the solar-aided boat with $5540 \mathrm{kWh}$ in a year, which reduces the annual $\mathrm{CO}_{2}$ emissions by 4.26 tons compared to a boat 


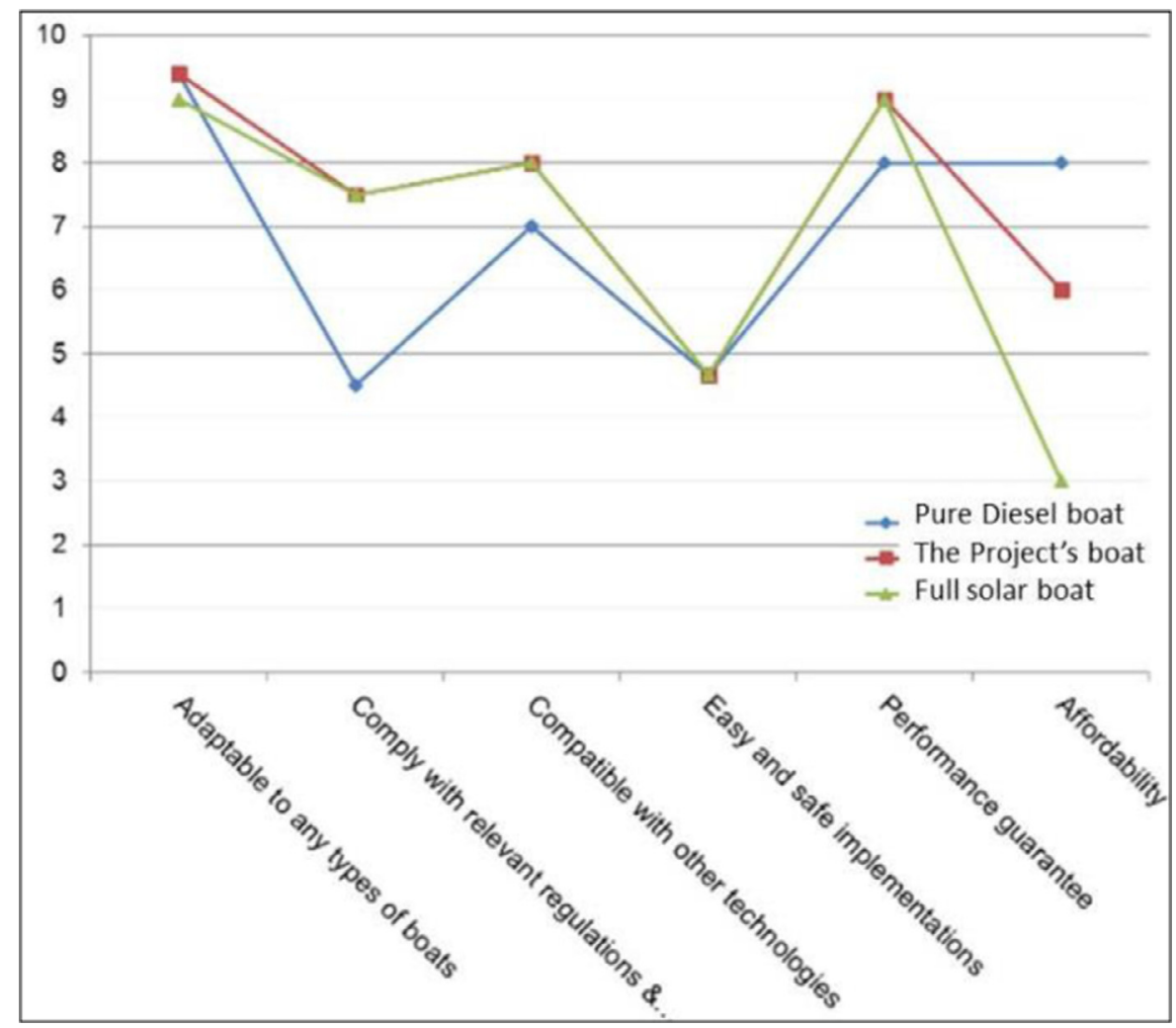

Fig. 2. Functional value characteristics per investigated competitive solution.

powered by diesel alone (United States Environmental Protection Agency October 2020). The simulation results indicated that the main limitation was the rooftop area, which was insufficient to convert the diesel-powered boat to a fully electric boat. The installed rooftop PV system can meet the service demands of the boat, while the diesel motor is more economical for propulsion.

\section{Results and Discussion}

\subsection{Motors and Battery Systems}

Considering the available technologies, solar boats require maximizing the PV area and battery capacity to facilitate long-distance travel. Electric motors with a power of up to $60 \mathrm{~kW}$ are commercially available. If a solar boat is assumed to have the same size and tonnage of the diesel-powered tourist boats in the study area as well as the same maximum speed of approximately $5 \mathrm{kn}$, two $10 \mathrm{~kW}$ motors may be sufficient. One example of such a motor is available from Aquawatt: type IEC 132 with a $100 \mathrm{~V}$ battery system and a cost of about 8000 EUR. With regard to the battery, lithium-ion batteries are more expensive than lead-acid batteries but are preferable because of their better deep charge behavior and higher number of loading cycles and thus longer lifetime. Such lithium-ion batteries are also commercially available. Lithium-ion battery systems for boats can be hidden on board and usually cost around $1000 \mathrm{EUR} / \mathrm{kWh}$, including the charge controller and management. Compared to in-house PV battery systems, which cost up to $2500 \mathrm{EUR} / \mathrm{kWh}$, these systems are much cheaper. However, a battery system with a capacity of $60 \mathrm{kWh}$ (also available from Aquawatt) would cost approximately 50,000 EUR. Table 4 summarizes the system cost (not including labor) for retrofitting a solar boat.
Table 4

\begin{tabular}{ll} 
Cost Summary. & \\
\hline Item Group & Cost (EUR) \\
\hline Photovoltaic System & 4000 \\
Construction & 5000 \\
Motors & 16,000 \\
Battery System & 50,000 \\
Total & 75,000 \\
\hline
\end{tabular}

\subsection{System Performance}

A battery capacity of $60 \mathrm{kWh}$ would allow a boat to operate for a maximum of $3 \mathrm{~h} / \mathrm{day}$, depending on the number of transported people and speed, until the battery is discharged. However, the system will need at least 3 days to recharge the battery if the battery is discharged and the boat not in use. A bigger battery would increase the range of the solar boat but also increase the recharge time. However, one approach would be for the boat to operate on the weekend and recharge during the week. A more practical option would be to use a diesel motor to supplement the battery capacity of the solar-powered system and extend the travel distance.

The boat size needs to be considered when assessing the potential of retrofitting it as a solar boat. Fig. 5 shows three scenarios considering the payoff of the solar boat depending on the battery capacity and in comparison to the reference diesel-powered boat. Further simulations were carried out to compare existing and new solar boats as well as a landside PV plant to supply boats docking in the harbor with electricity.

Two options were analyzed assuming a battery cost of 1000 EUR/kWh, PV panel cost of $950 \mathrm{EUR} / \mathrm{kWp}$ and cost of 16,000 EUR for upgrading the reference diesel-powered boat with an electric motor. The $60 \mathrm{kWh}$ and $120 \mathrm{kWh}$ battery systems were assessed. The simulation results indicated that the PV panels provide $1 / 4$ of 


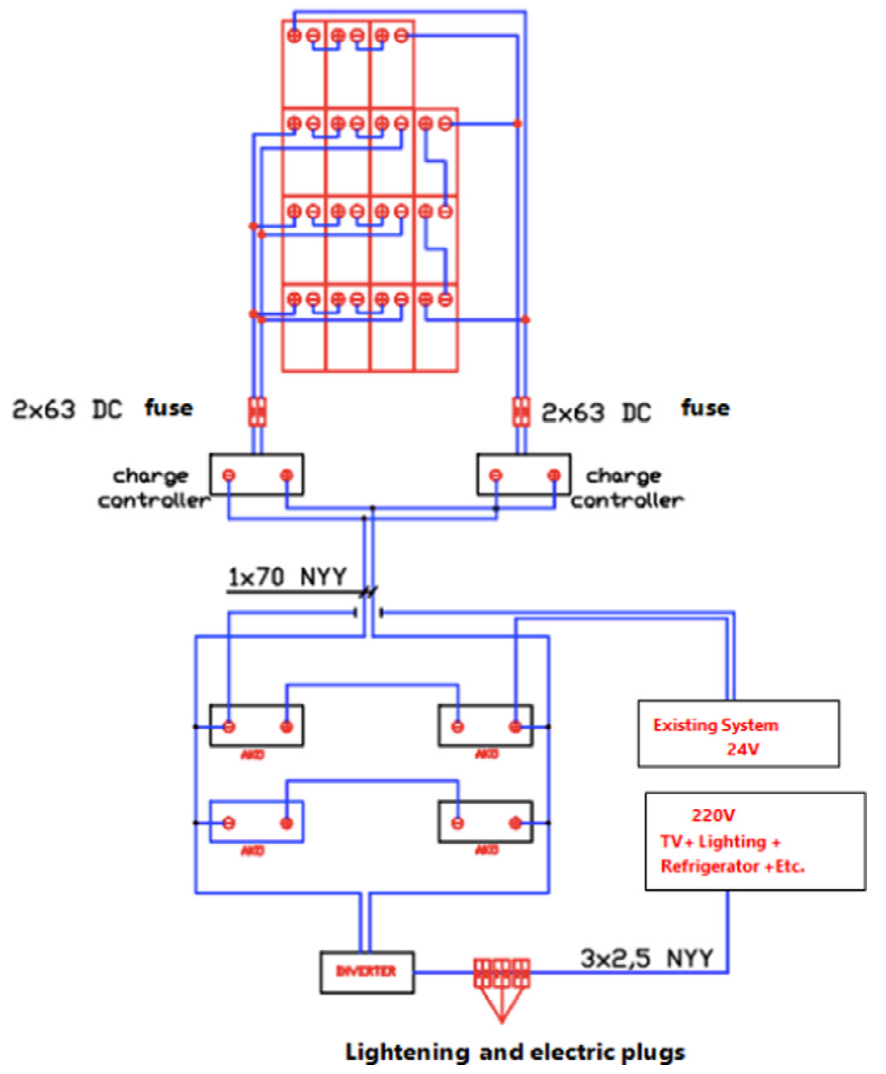

Fig. 3. Single line diagram of installed PV system for the solar -aided boat.

the annual required energy to drive the boat. Thus, the remaining energy must be purchased from the electricity grid. Gasoline prices were taken from the Global Petrol Price Index (Global petrol prices December 2019), and electricity prices were taken from Eurostat (Global electrical prices December 2019). Rates for inflation were taken from trade economics (Inflation Rates of Turkey December 2019). In addition, the boat would be noiseless and could access regions where no power sockets and gas refill stations are available. Compared to a regular diesel-powered boat, a solar boat with a more efficient motor, solar panels, and $60 \mathrm{kWh}$ battery systems would have a payback period of approximately 9 years. However, this system is not self-sufficient and needs to connect to the grid to recharge the battery at night.
Table 5

Energy output with study area coordinates.

\begin{tabular}{lll}
\hline Month & Solar Radiation & Energy Output \\
\hline & $\left(\mathbf{k W h} / \mathrm{m}^{2} / \mathbf{d a y}\right)$ & $\mathbf{( k W h})$ \\
January & 3.69 & 9.295 \\
February & 4.50 & 10.121 \\
March & 5.96 & 14.522 \\
April & 6.48 & 15.036 \\
May & 7.34 & 16.788 \\
June & 7.94 & 17.391 \\
July & 7.96 & 17.825 \\
August & 7.70 & 17.071 \\
September & 7.09 & 15.340 \\
October & 5.87 & 13.724 \\
November & 4.25 & 9.917 \\
December & 3.65 & 9.073 \\
Annual & $\mathbf{6 . 0 4}$ & $\mathbf{1 6 6 . 1 0 3}$ \\
\hline
\end{tabular}

In contrast to the previous scenario, a solar boat with $120 \mathrm{kWh}$ battery systems would have a payback period of approximately 13 years and would be 100\% energy self-sufficient. Fig. 6 shows the net present value of the diesel-powered boat and new solar boats.

\subsection{On-grid PV Power Plant and Potential Benefits}

The favorable conditions of the study area in terms of solar radiation (Table 5) and availability of a legislative structure on solar power provide an interesting potential alternative for boat owners. The incentive structure for generating solar energy is only relevant in a scenario where electricity is generated from a grid-connected solar power system and used to charge battery systems of boats. The development of such a system would provide local authorities or boat owners with an opportunity to transition to $100 \%$ renewable energy consumption while being financially feasible through the sale of surplus electricity with high feed-in tariffs. The available incentive in the study region is a minimum of $0.133 \mathrm{USD} / \mathrm{kWh}$ $(0.11 € / \mathrm{kWh})$. This could be achieved either through a private company (initiated by the boat owners, municipality, energy production company, or combination of these) or through an established energy corporation.

\subsubsection{Sizing}

The size of the on-grid PV power plant was estimated assuming a demand of $120,000 \mathrm{kWh}$ /day in the peak times of July and August. This demand was calculated by assuming that 40 boats make 5 trips per day with each trip requiring $60 \mathrm{kWh}$ of energy. This de-

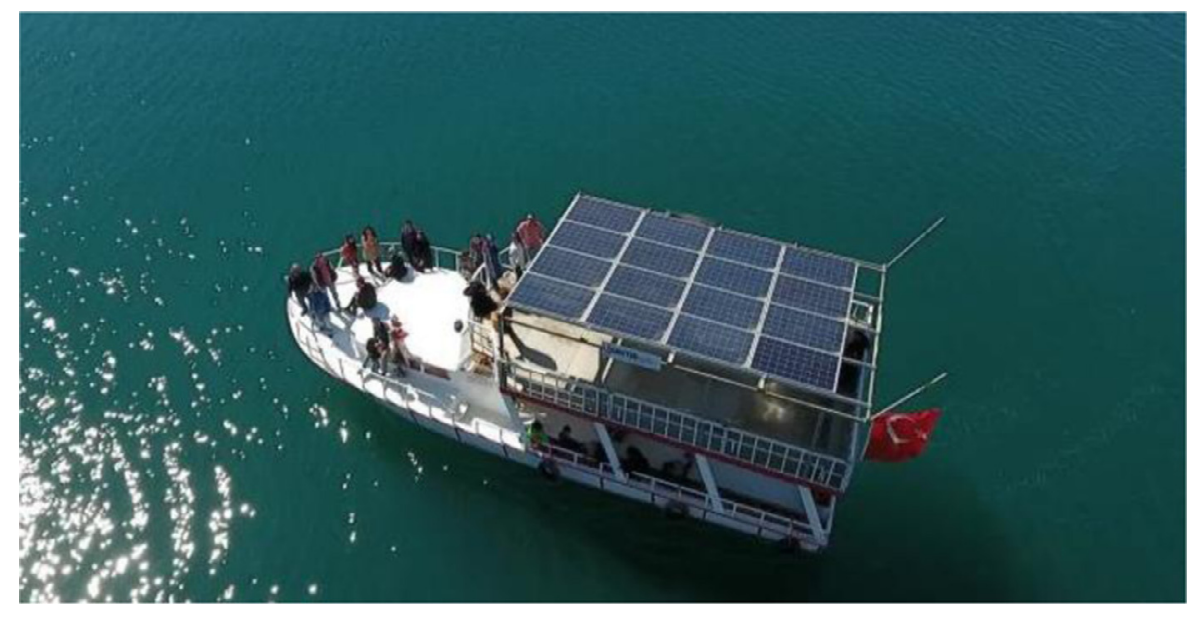

Fig. 4. The "Case Study" solar boat on the River Euphrates, Turkey. 


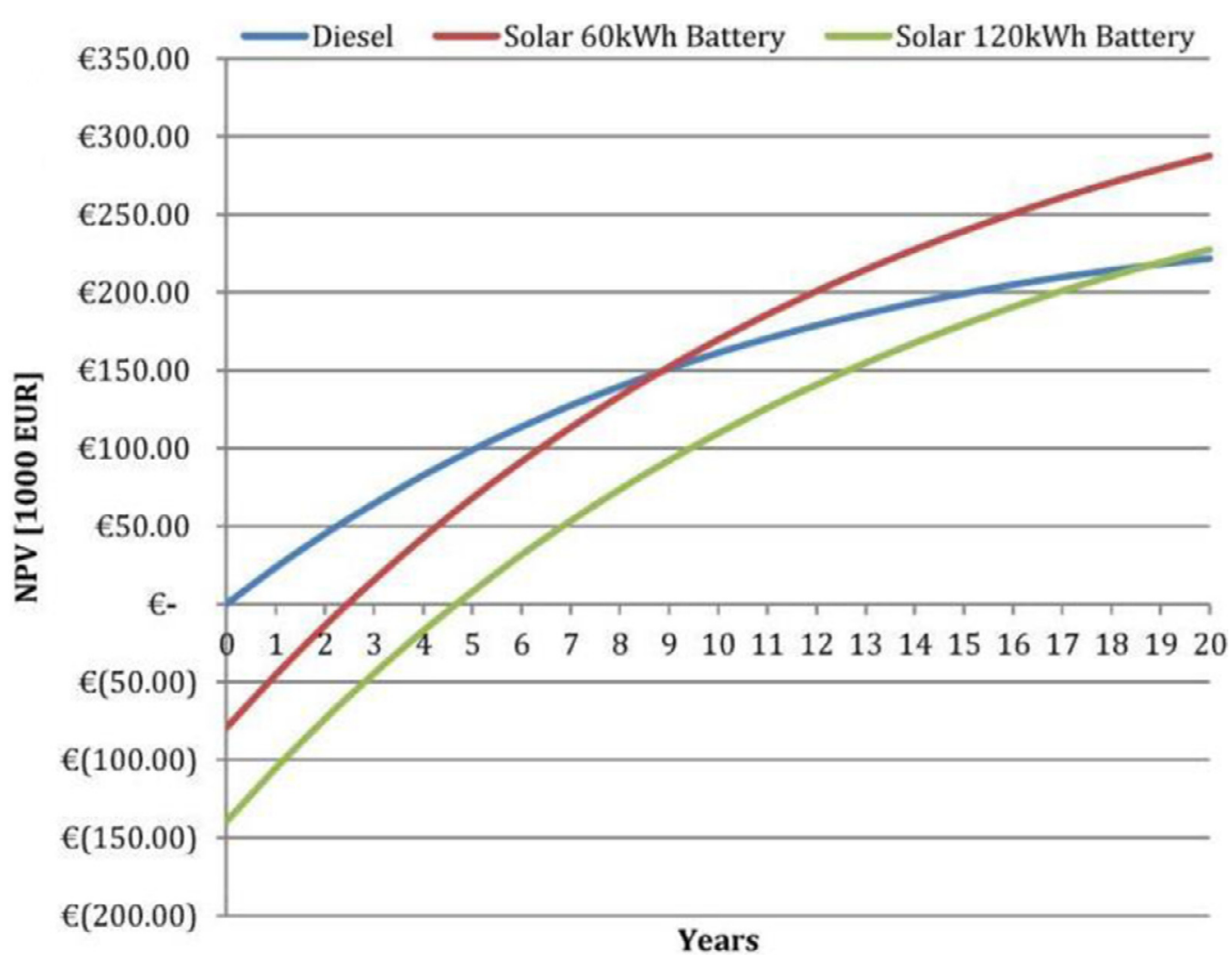

Fig. 5. Net Present Value of Diesel Boats and Solar Boats.

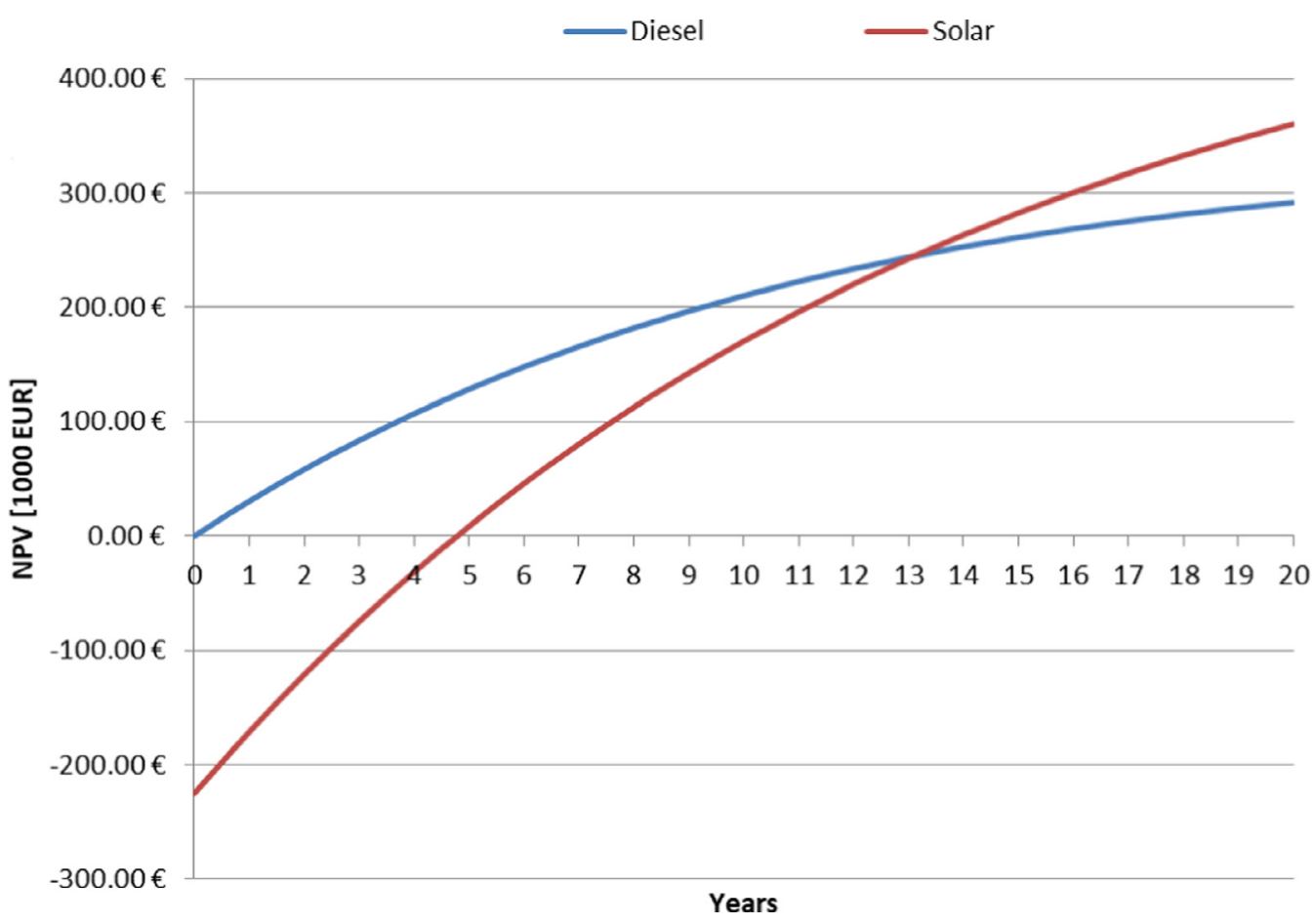

Fig. 6. Net Present Value of Diesel Boats and Solar Boats.

mand can be reduced to $3600 \mathrm{kWh} /$ day with more energy-efficient systems, where a 20 -ton vessel with 60 passengers traveling at 5 $\mathrm{kn}$ would only requires $48 \mathrm{kWh}$ for $8 \mathrm{~h}$ of travel. Assuming that all boats work at full capacity (i.e., 40 boats makes 5 trips a day) on weekends (Saturday and Sunday) and at 30\% capacity during weekdays, the energy demand is $50,400 \mathrm{kWh} / \mathrm{month}$ for July and
August. In August, a PV power plant with an installed capacity of $300 \mathrm{kWp}$ would generate 53,480 kWh of energy. This production is enough to cover even the peak loads of the boats without relying on electricity from the grid. Tourism statistics for Gaziantep (Gaziantep tourism, 2019) indicate the possibility of variation in the peak load. However, a larger installation capacity than required 
Table 6

Cost ratio of the PV components.

\begin{tabular}{cc}
\hline PV System Investment Items & Share within the total cost \\
\hline Panel & $45 \%-50 \%$ \\
\hline Inverter & $5 \%-10 \%$ \\
\hline Electrical equipment & $10 \%-15 \%$ \\
\hline Construction works & $10 \%-15 \%$ \\
\hline Labor cost & $5 \%-15 \%$ \\
\hline Unit cost of total investment* & 0.95 USD/W for Land Type \\
1.3 USD/W for Roof Type
\end{tabular}

*VAT Exemption is provided for this type of EU project activity.

Table 7

Maintenance cost shares.

\begin{tabular}{lll}
\hline Annual Operational Cost items & Share within the total cost & \\
\hline & Land Type & Roof Type \\
Maintenance and Repair Costs & $35 \%-40 \%$ & $65 \%-70 \%$ \\
Personal Costs & $35 \%-40 \%$ & - \\
System Fee & $25 \%-30 \%$ & - \\
Insurance & $5 \%-10 \%$ & $25 \%-30 \%$ \\
Unexpected costs & $0.5 \%-1 \%$ & $10 \%$ \\
\hline
\end{tabular}

is permissible because the surplus electricity can be fed into the national grid with a guaranteed feed-in tariff.

\subsubsection{Overview of Investment Costs}

Table 6 summarizes the breakdown for turnkey PV installation. The PV panels, inverter, electromechanical components, and cabling make up $90 \%$ of the total investment costs.

\subsubsection{Overview of Operating Costs}

The operating costs are low relative to the initial investment costs. The most significant operating costs consist of security shares and system usage fees. Table 7 briefly explains the shares

Table 8

A sample of $300 \mathrm{~kW}$ (land type) PV Power Plant cost shares.

\begin{tabular}{ll}
\hline Total Initial Cost* & 285,000 USD \\
\hline System Connection Cost & 18,000 USD \\
Land Cost & 27,000 USD \\
Unexpected Costs & 6000 USD \\
VAT & N.A. \\
Total Initial Cost & 336,000 USD \\
Electricity generation & $498,309 \mathrm{kWh} /$ year \\
Estimated electricity generation & 25 year \\
Technical lifetime & $0.5 \%$ \\
Estimated annual performance loss & $6000 \mathrm{~m}^{2}$ \\
Required land area & \\
Operational Costs & $6000 \mathrm{USD}$ \\
Maintenance and Repair Costs & $10,000 \mathrm{USD}$ \\
Personal Costs & $4000 \mathrm{USD}$ \\
System Usage Fee & $1000 \mathrm{USD}$ \\
Unexpected costs & $1200 \mathrm{USD}$ \\
Insurance & $22,200 \mathrm{USD}$ \\
Total operational Cost & \\
Annual Income & $13.3 \mathrm{USD}$ cent/kWh \\
Applied tariff & 66,275 USD/year \\
Annual Income** &
\end{tabular}

*The above financial indicators only provide an estimate on installation of a $300 \mathrm{kWp}$ PV power plant and do not include the cost of interventions for the boat or the required charging station.

** It should be also noted that a portion of the electricity generated will be used to charge the batteries of the boats. The selfconsumption is not taken into consideration and assumed that all the generated electricity is exported to the grid when calculating the annual income. of costs. Table 8 presents the financial indicators of a sample 300 kW PV power plant based on the above assumptions.

\section{Conclusions and Recommendations}

This study compared solar boats with their conventional fossil fuel competitors in terms of the energy consumption and production to evaluate the effectiveness of different approaches and the feasibility of achieving a sustainable solution. Three alternative sustainable transportation scenarios and an on-grid power plant design were analyzed and compared to diesel-powered tourist boats. The case study showed that a solar-aided boat with a diesel motor and PV panels installed on the rooftop with $9.8 \mathrm{kWh}$ batteries to meet the energy demands of internal services can be a sustainable solution. This design reduces the diesel fuel consumption by $15 \%$ and annual $\mathrm{CO}_{2}$ emissions by 4.26 tons while producing $5540 \mathrm{kWh}$ of energy. These results will help increase awareness of solar boats and their potential contribution to combating climate change. To realize a fully electric boat, two options were considered. According to the simulation results, the solar boat with 60 kWh batteries pays back its initial investment in 9 years, while the boat with $120 \mathrm{kWh}$ batteries does so in 13 years. A $300 \mathrm{~kW}$ on-grid PV plant was analyzed for its ability to meet the energy demands of a whole tourist boat fleet, and it was calculated to reduce $\mathrm{CO}_{2}$ emissions by 330 tons each year.

The results of this study demonstrate the benefits of various off-grid rooftop PV systems, which can be adapted for sustainable transportation to reduce the operating costs of boat owners. This study also promotes the transition of boats to renewable energy sources. The presented systems provide good examples to local authorities on how to achieve sustainability goals to combat climate change. For future research on sustainable transportation, more efficient solar boats should be designed, such as construction with lighter materials and embedding PV panels in the hull.

\section{Funding}

This study is funded by EuropeAid with the contract number: TR2011/0135.15-01/30. Istanbul Technical University Graduated Students' Association, Gaziantep, as applicant, Hasan Kalyoncu University (HKU), as co-applicant, University of Natural Resources and Life Sciences (BOKU), as co-applicant and TBW research GesmbH; Austria, as associate. The Title of the Action was "Civil Dialogue for Introducing the Climate Change Policy of EU to Turkey". Target country(ies) or region(s): Zeugma, Rumkale, Halfeti in Gaziantep, Turkey.

\section{Declaration of Competing interest}

The authors declare that they have no known competing financial interests or personal relationships that could have appeared to influence the work reported in this paper.

The authors declare the following financial interests/personal relationships which may be considered as potential competing interests.

\section{References}

Nations, United, 2015. Transforming our world: the 2030 Agenda for Sustainable Development. Res. Gen. Assem.. 70/1 https://www.un.org/en/development/desa/ population/migration/generalassembly/docglobalcompact/A_RES_70_1_E.pdf Accessed on 18 December 2019.

Byrnes, T.A., Warnken, J., 2006. Greenhouse Gas Emissions from Marine Tours: A Case Study of Australian Tour Boat Operators. J. Sust. Tourism 14 (3), 255-270. doi:10.1080/09669580608669058.

Kokkranikal, J., McLellan, R., Baum, T., 2003. Island Tourism and Sustainability: A Case Study of the Lakshadweep Islands. J. Sust. Tourism 11 (5), 426-447. doi:10. 1080/09669580308667214. 
Eid, B.M, Abd Rahim, N., Selvaraj, J., El Khateb, A.H., 2014. Control methods and objectives for electronically coupled distributed energy resources in microgrids: A review. IEEE Syst. J. 10, 446-458.

Veilleux, G, Potisat, T, Pezim, D., Ribback, C., Ling, J., Krysztofiński, A., Ahmed, A., Papenheim, J., Pineda, A.M., Sembian, S., et al., (2020) Techno-economic analysis of microgrid projects for rural electrification: A systematic approach to the redesign of Koh Jik off grid case study Energy for Sustainable Development 54 1-13.

Miraz Fulhu, Muaviyath Mohamed, Susan Krumdieck; (2019), Voluntary demand participation (VDP) for security of essential energy activities in remote communities with case study in Maldives Energy for Sustainable Development 49 27-38, https://doi.org/10.1016/j.esd.2019.01.002.

Djorup, S., ZinckThellufsen, J., Sorknæs, P., 2018. The electricity market in a renewable energy system. Energy 162 (1), 148-157. November 2018 https://doi.org/ 10.1016/j.energy.2018.07.100 .

Bulut, U, Muratoglu, G, 2018. Renewable Energy in Turkey: Great Potential, Low But Increasing Utilization, And An Empirical Analysis On Renewable Energy-Growth Nexus. Energy Policy 123, 240-250.

Blancas, F.J., Lozano-Oyola, M., Gonz_alez, M., Caballero, R., 2018. A dynamic sustainable tourism evaluation using multiple benchmarks. J. Clean. Prod. 174, 1190-1203.

Mihalic, T., 2016. Sustainable-responsible tourism discourse Towards 'responsustable' tourism. J. Clean. Prod 111, 461-470.

Wang, S., Du, J., Li, S., He, H., Xu, W., 2019. Impact of tourism activities on glacial changes based on the tourism heat footprint (THF) method. J. Clean. Prod. 215, 845-853.

Azam, M., Alam, M.M., Hafeez, M.H., 2018. Effect of tourism on environmental pollution: further evidence from Malaysia. Singapore Thailand. J. Clean. Prod 190, $330-338$.

Høyer, K.G., 2000. Sustainable tourism or sustainable mobility? The Norwegian case, J. Sustain. Tour. 8 (2), 147-160.

Del Pizzo, A., Polito, R.M., Rizzo, R., Tricoli, P., 2010. Design criteria of on-board propulsion for hybrid electric boats. In: The XIX International Conference on Electrical Machines - ICEM 2010, Rome, Italy, pp. 1-6.

Bianucci, M., Merlino, S., Ferrando, M., Baruzzo, L., 2015. The Optimal Hybrid/ electric Ferry for the Liguria Natural Parks. OCEANS 2015. IEEE, Genova, pp. 1-10.

Łebkowski, A., 2017. Researching the impact of electric boat hull aeration energy consumption. Sci. J. Gdynia Marit. Univ. 98, 148-156.
Karimpour, R., Karimpour, M., 2016. Development of hybrid propulsion system for energy management and emission reduction in maritime transport system. Open J. Mar. Sci. 6, 482-497.

Bigerna, S, Micheli, S., Polinori, P., 2019. Willingness to pay for electric boats in a protected area in Italy: A sustainable tourism perspective. J. Cleaner Prod. 224, 603-613.

Zhao, X., Ke, Y., Zuo, J., Xiong, W., Wu, P., 2020. Evaluation Of Sustainable Transport Research in 2000-2019. J. Cleaner Prod. 256, 120404.

Faulin, J, Grasman, S.E, Juan, A.A, Hirsch, P, 2019. Sustainable transportation: concepts and current practices, in: Sustainable Transportation and Smart Logistics. Elsevier, pp. 3-23.

Evan Mills, Tim Gengnagel, Philipp Wollburg; (2014). Solar-LED Alternatives To FuelBased Lighting For Night Fishing; Energy for Sustainable Development 21, 30-41.

Łapko, A., 2016. The use of auxiliary electric motors in boats and sustainable development of nautical tourism - cost analysis, the advantages and disadvantages of applied solutions, 2nd International Conference "Green Cities - Green Logistics for Greener Cities". Trans. Res. Procedia 16, 323-328.

Spyropoulos, V, Mitronikas, E, D.D, 2013. A review on the faults of electric machines used in electric ships. Adv. Power Electron. 2013.

https://www.boote-magazin.de/ratgeber/berechnungen.html. Accessed on 17 April 2017.

PV*SOL software; https://pvsol.software/en/features-pricing, Accessed on 12 August 2018.

Solar Irradiation Turkey, http://www.yegm.gov.tr/MyCalculator Accessed: 2019.

EU Directive 92/75/EEC; https://eur-lex.europa.eu/legal-content/EN/ALL/?uri= CELEX\%3A31992L0075, Accessed on 17 April 2017.

United States Environmental Protection Agency, Greenhouse Gases Equivalencies Calculator-Calculations and Reference; https://www.epa.gov/energy/ greenhouse-gases-equivalencies-calculator-calculations-and-references, Accessed on 10 October 2020.

Global petrol prices. https://www.globalpetrolprices.com/diesel_prices/ Accessed on 18 December 2019.

Global electrical prices. https://ec.europa.eu/eurostat/statistics-explained/index.php/ Electricity_price_statistics Accessed: on 18 December 2019.

Inflation Rates of Turkey. https://de.tradingeconomics.com/turkey/ consumer-price-index-cpi Accessed on 18 December 2019.

Gaziantep tourism, https:/gaziantep.ktb.gov.tr/TR-127941/turizm-isletme-belgelitesislerde-konaklayan-turist-say-.html, Accessed on 18 November 2019. 